\title{
Identification and Counting of Carbonyl and Hydroxyl Functionalities in Protonated Bifunctional Analytes by Using Solution Derivatization Prior to Mass Spectrometric Analysis Via Ion-Molecule Reactions
}

\author{
Jayalakshmi Somuramasami, ${ }^{\mathrm{a} *}$ Brian E. Winger, ${ }^{\mathrm{b}}$ Todd A. Gillespie, ${ }^{\mathrm{b}}$ and \\ Hilkka I. Kenttämaa ${ }^{a}$ \\ a Department of Chemistry, Purdue University, West Lafayette, Indiana, USA \\ ${ }^{\mathrm{b}}$ Eli Lilly and Company, Indianapolis, Indiana, USA
}

A mass spectrometric method has been developed for the identification of carbonyl and hydroxyl functional groups, as well as for counting the functional groups, in previously unknown protonated bifunctional oxygen-containing analytes. This method utilizes solution reduction before mass spectrometric analysis to convert the carbonyl groups to hydroxyl groups. Gas-phase ion-molecule reactions of the protonated reduced analytes with neutral trimethylborate (TMB) in a FT-ICR mass spectrometer give diagnostic product ions. The reaction sequence likely involves three consecutive steps, proton abstraction from the protonated analyte by TMB, addition of the neutral analyte to the boron reagent, and elimination of a neutral methanol molecule. The number of methanol molecules eliminated upon reactions with TMB reveals the number of hydroxyl groups in the analyte. Comparison of the reactions of the original and reduced analytes reveals the presence and number of carbonyl and hydroxyl groups in the analyte. (J Am Soc Mass Spectrom 2010, 21, 773-784) @ 2010 American Society for Mass Spectrometry

$\mathrm{O}$ ne of the major research areas in mass spectrometry (MS) is the development of better methods for the identification of unknown compounds directly in mixtures. Techniques that are currently utilized for these analyses, such as NMR and X-ray crystallography [1], are powerful but timeconsuming, and often require high-purity samples and relatively large quantities of the analytes. Tandem mass spectrometry (MS/MS) is ideally suited for obtaining structural information on species present in mixtures because it does not require pure samples, consumes a minimal amount of sample, and is fast, highly sensitive, and has a high specificity of detection [2,3]. Typically, MS/MS experiments involve the generation of protonated analytes that are mass-selected and characterized by techniques such as exact mass measurements [4], collision-activated dissociation [5] (CAD), and H/D exchange reactions [6]. Though a wealth of information can be obtained from these experiments, unambiguous identification of the functional groups in unknown compounds is difficult to achieve.

Address reprint requests to Dr. H. I. Kenttämaa, Department of Chemistry, Purdue University, BRWN Building, 560 Oval Drive, West Lafayette, IN, 47907, USA. E-mail: hilkka@purdue.edu

* Current address: Merck Corporation, Union, NJ 07083, USA.
Gas-phase ion-molecule reactions present a powerful approach for obtaining structurally informative data for a variety of compounds, from simple organic molecules to complex biomolecules, because they occur at low energies and can lead to a diagnostic product ion that affords functional group identification [7]. In some cases, ionmolecule reactions combined with collision-activated dissociation have provided structurally informative fragment ions [8]. Past work on ion-molecule reactions has focused mainly on obtaining functional group information for neutral analytes by using ionic reagents $[9,10]$. These reagents include boron compounds. For example, gasphase reactions of dimethoxyborenium ion, a major fragment ion of protonated trimethylborate (TMB), and the TMB molecular ion, have been demonstrated to allow the identification of functional groups present in neutral alcohols, aldehydes, ethers, ketones, and some biologically active molecules containing hydroxyl groups [9]. Few studies have also appeared wherein neutral reagents were used to identify the functional groups present in ionized analytes [11]. Identification of functional groups in ionic analytes is of special interest since this approach is needed for the identification of analytes evaporated and protonated by the widely used techniques MALDI and ESI.

A previous study from our laboratories resulted in an ion-molecule reaction-based method for the partial
(C) 2010 American Society for Mass Spectrometry. Published by Elsevier Inc. $1044-0305 / 10 / \$ 32.00$

doi:10.1016/j.jasms.2009.11.008
Published online December 4, 2009 Received September 3, 2009 Revised November 18, 2009 Accepted November 23, 2009 
identification of functional groups in protonated bifunctional oxygen-containing compounds, including diols, hydroxyethers. and hydroxyketones [11i]. However, the less basic functional group in protonated hydroxyketones, the hydroxyl group, could not be identified in the presence of the keto group. We report here a method combining solution derivatization [12-14] and mass spectrometric ion-molecule reactions that allows the identification and counting of both hydroxyl and keto functionalities in protonated bifunctional compounds.

\section{Experimental}

The experiments were performed in two different FTICR instruments, an Extrel (Madison, WI, USA) model FTMS 2001 and a Finnigan (San Jose, CA, USA) model FTMS 2001, each equipped with an Odyssey data station. These instruments contain a dual cell consisting of two identical cubic 2-in. cells separated by a conductance limit plate. Each dual cell is aligned collinearly with the magnetic field of a superconducting magnet. The conductance limit plate has a 2-mm hole in the center for the transfer of ions from one side into the other. The conductance limit plate and the two end trapping plates were maintained at $+2.0 \mathrm{~V}$ in both the instruments unless otherwise stated. The Extrel FTMS 2001 mass spectrometer contains a 3 T superconducting magnet operated at $\sim 2.7 \mathrm{~T}$, and two Balzers (Amherst, $\mathrm{NH}$, USA) turbomolecular pumps (330 L/s), each backed by an Alcatel (Hingham, MA, USA) 2012 mechanical pump. Finnigan FTMS 2001 mass spectrometer contains a $3 \mathrm{~T}$ superconducting magnet, and two Edwards (Tewksbury, MA, USA) Diffstak 160 diffusion pumps (700 L/s), each backed by an Alcatel 2012 mechanical pump. A nominal baseline pressure of less than $1 \times 10^{-9}$ Torr was measured in both instruments by Bayard-Alpert ionization gauges located on each side of the dual cell. Liquid samples were introduced into the instruments either by using a batch inlet system equipped with Andonian (New Bedford, MA, USA) leak valves or via a Varian leak valve (Palo Alto, CA, USA). A manual solids probe was used to introduce solid samples into the Extrel FTMS 2001 instrument, whereas an automatic solids probe was used to introduce solid samples into the Finnigan FTMS 2001 instrument.

All chemicals were purchased from the SigmaAldrich Co. (St. Louis, MO, USA) and used without further purification. The analytes were protonated by self-chemical ionization (self-CI). This was achieved by allowing the fragment ions of the neutral analytes generated upon electron ionization (EI) to react with the neutral analyte for a certain period of time (1-10 s). Typical electron ionization parameters were 0.05-3.0 s electron beam time, 25-70 eV electron energy, and 8.0

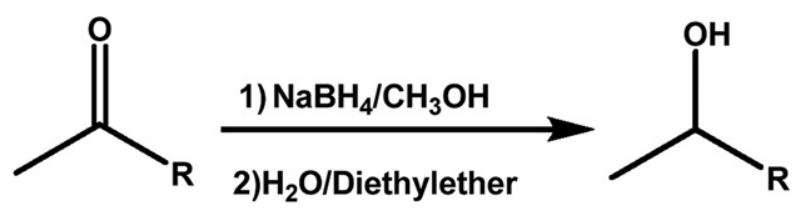

Reagents:

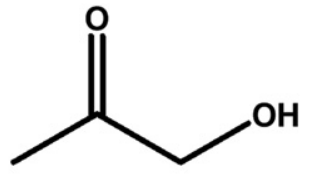

3-Hydroxy-2-propanone

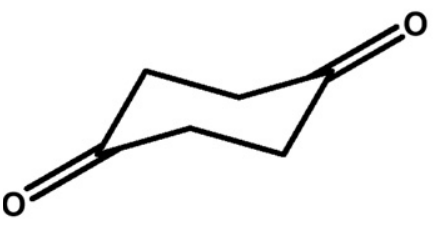

1,4-Cyclohexanedione

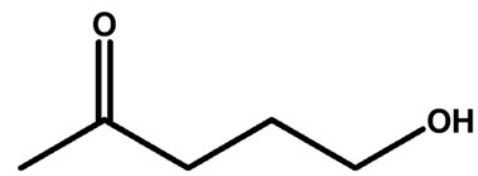

5-Hydroxy-2-pentanone

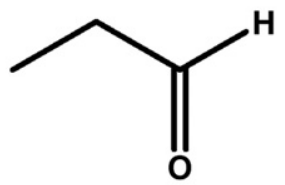

Propionaldehyde

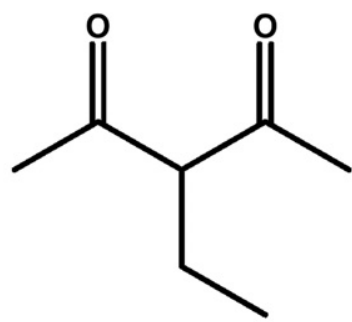

3-Ethyl-2,4pentanedione<smiles>CC(C)(C=O)CO</smiles>

2,2-Dimethyl-3hydroxypropanal 
Table 1. Derivatization products $(\mathrm{m} / \mathrm{z}$ values and formation reactions) of reactions between protonated carbonyl compounds and $T M B$, and the SORI-CAD fragment ions and $\mathrm{H} / \mathrm{D}$ exchange $\left(\mathrm{D}_{2} \mathrm{O}\right)$ products of the singly derivatized carbonyl compounds

\begin{tabular}{|c|c|c|c|c|}
\hline $\begin{array}{l}\text { Protonated analyte } \\
\left(\mathrm{m} / \mathrm{z} \text { of }(\mathrm{M}+\mathrm{H})^{+}\right)\end{array}$ & $\begin{array}{c}\text { Proton } \\
\text { affinity } \\
\text { (kcal/mol) }\end{array}$ & $\begin{array}{l}\text { Singly derivatized analyte } \\
\text { (adduct }-\mathrm{CH}_{3} \mathrm{OH} \text { ) and other } \\
\text { products }{ }^{\mathrm{a}}(\mathrm{m} / \mathrm{z})\end{array}$ & $\begin{array}{l}\text { SORI-CAD fragments of } \\
\text { adduct }-\mathrm{CH}_{3} \mathrm{OH}(\mathrm{m} / \mathrm{z})\end{array}$ & $\begin{array}{c}\mathrm{H} / \mathrm{D} \text { exchange of } \\
\text { adduct }-\mathrm{CH}_{3} \mathrm{OH} \\
(\mathrm{m} / \mathrm{z})\end{array}$ \\
\hline Propanaldehyde (59) & $187.9^{c}$ & $\begin{array}{l}\left(1^{\circ}\right) \text { Adduct }-\mathrm{CH}_{3} \mathrm{OH}(131) \\
\left(1^{\circ}\right) \mathrm{TMB}+\mathrm{H}^{+}(105) \\
\left(2^{\circ}\right) 2 \mathrm{TMB}+\mathrm{H}^{+}-\mathrm{CH}_{3} \mathrm{OH}(177)\end{array}$ & $\mathrm{B}\left(\mathrm{OCH}_{3}\right)_{2}^{+}(73)$ & $\begin{array}{l}\text { No } H / D \text { exchange } \\
\text { product }\end{array}$ \\
\hline 3-Hydroxy-2-propanone (75) & $198^{d}$ & Adduct $-\mathrm{CH}_{3} \mathrm{OH}(147)$ & Adduct $-2 \mathrm{CH}_{3} \mathrm{OH}(115)$ & $\begin{array}{l}\mathrm{H} / \mathrm{D} \text { exchange } \\
\text { product }(148) \\
\text { Adduct }-2 \mathrm{CH}_{3} \mathrm{OH} \\
(115)\end{array}$ \\
\hline $\begin{array}{l}\text { 2,2-Dimethyl-3-hydroxypropanal } \\
\text { (103) }\end{array}$ & & Adduct $-\mathrm{CH}_{3} \mathrm{OH}$ (175) & Adduct $-2 \mathrm{CH}_{3} \mathrm{OH}(143)$ & $\begin{array}{l}\text { No } H / D \text { exchange } \\
\text { product }\end{array}$ \\
\hline 5-Hydroxy-2-pentanone (103) & $\sim 221^{d}$ & No reaction & $\mathrm{N} / \mathrm{A}^{\mathrm{b}}$ & $\mathrm{N} / \mathrm{A}^{\mathrm{b}}$ \\
\hline 3-Ethyl-2,4-pentanedione (129) & & Adduct - $2 \mathrm{CH}_{3} \mathrm{OH}(169)$ & $N / A^{b}$ & $\begin{array}{l}\text { No } \mathrm{H} / \mathrm{D} \text { exchange } \\
\text { product }\end{array}$ \\
\hline 1,4-Cyclohexanedione (113) & $194.2^{c}$ & $\begin{array}{l}\left(1^{\circ}\right) \text { Adduct }-\mathrm{CH}_{3} \mathrm{OH}(185) \\
\left(1^{\circ}\right) \mathrm{TMB}+\mathrm{H}^{+}(105) \\
\left(2^{\circ}\right) 2 \mathrm{TMB}+\mathrm{H}^{+}-\mathrm{CH}_{3} \mathrm{OH}(177)\end{array}$ & $\begin{array}{l}\text { Adduct - } \mathrm{H}_{2} \mathrm{O}(167) \\
\text { Adduct - } 2 \mathrm{CH}_{3} \mathrm{OH}(153) \\
\text { Adduct - } \mathrm{HOB}\left(\mathrm{OCH}_{3}\right)_{2}(95) \\
\mathrm{B}\left(\mathrm{OCH}_{3}\right)_{2}^{+}(73)\end{array}$ & $\begin{array}{l}\text { No H/D exchange } \\
\text { product }\end{array}$ \\
\hline
\end{tabular}

${ }^{a}$ Only derivatization products containing the most abundant ${ }^{11} \mathrm{~B}$ isotope are listed (all products observed also contain a ${ }^{10} \mathrm{~B}$ isotope present in an abundance of $25 \%$ relative to the most stable isotope).

${ }^{\mathrm{b}} \mathrm{N} / \mathrm{A}=$ Singly derivatized analyte was not observed and hence SORI-CAD was not performed.

${ }^{\mathrm{c}}$ Reference [22].

${ }^{\mathrm{d}}$ Reference [11i].

$\left(1^{\circ}\right)=$ primary product; $\left(2^{\circ}\right)=$ secondary product.
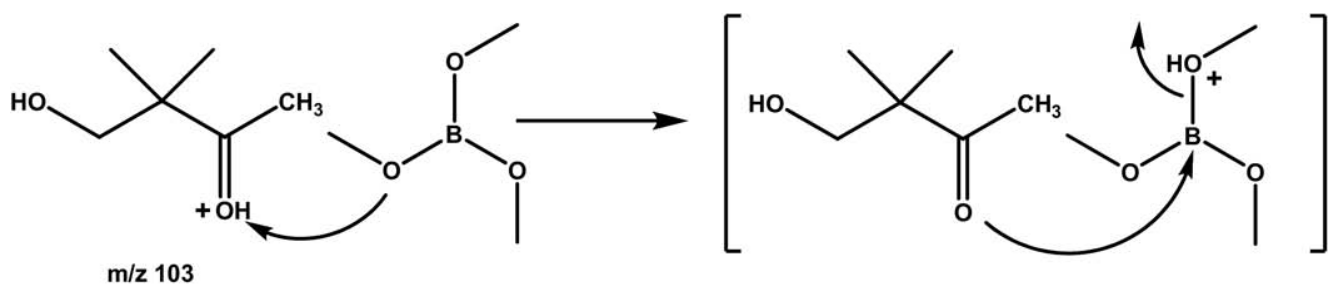

$\mathrm{m} / \mathbf{z} 103$
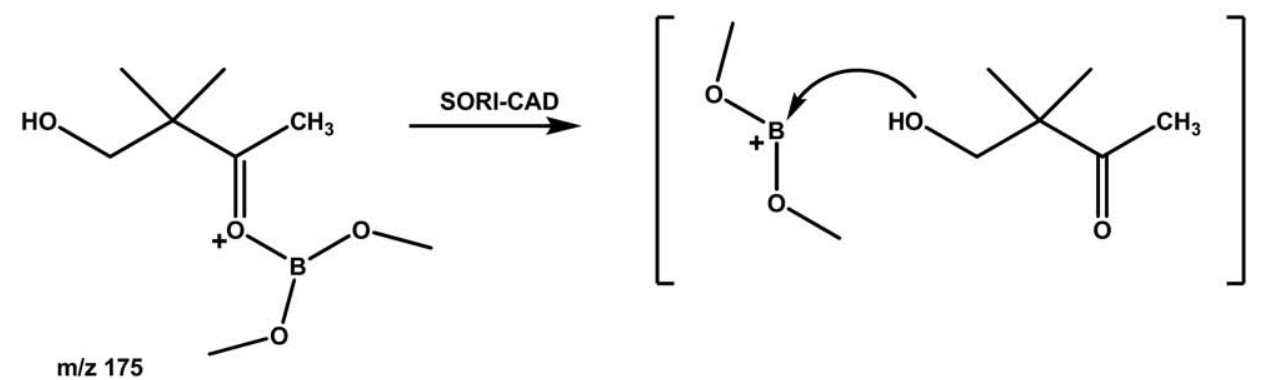

$\mathrm{m} / \mathbf{z} 175$

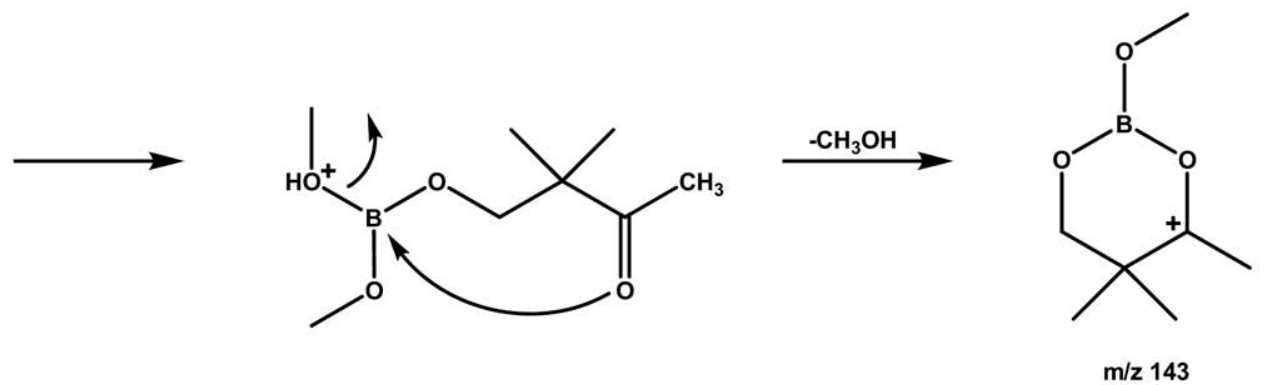

Scheme 2 
$\mu A$ filament current. Nominal base pressure of the neutral reagents varied between $4.0 \times 10^{-8}$ and $6.0 \times$ $10^{-8}$ Torr, as measured by the ion gauges. All the ions in the other side of the dual cell were removed before ion transfer by changing the remote trapping plate voltage from $+2.0 \mathrm{~V}$ to $-2.0 \mathrm{~V}$ for $12 \mathrm{~ms}$. The protonated analyte was transferred into the other cell by grounding the conductance limit plate (75-140 $\mu \mathrm{s})$. The transferred ions were cooled for about $1 \mathrm{~s}$ via IR emission [15] and by collisions with Ar present at about $10^{-5}$ torr. The protonated analyte was isolated by using a stored-waveform inverse Fourier transform [16] (SWIFT) excitation pulse to eject all unwanted ions, and allowed to react with TMB (reaction times were from 0.05 to about $500 \mathrm{~s}$ ).

Some of the reaction product ions were further probed by SWIFT isolation and subjecting them to either sustained off-resonance irradiated collisionactivated dissociation [17] (SORI-CAD) or H/D exchange reactions. In these experiments, the ion of interest was generated in one cell and then transferred into the other cell fur further studies. SORI-CAD experiments utilized off-resonance excitation of the isolated ion at a frequency $\pm 1000 \mathrm{~Hz}$ off the cyclotron frequency of the ion. This experiment was carried out for about $1 \mathrm{~s}$ in the presence of an inert gas ( $10^{-5}$ Torr of argon). H/D exchange reactions were carried out by allowing the ions to react with $\mathrm{D}_{2} \mathrm{O}$ (reaction times varied from 0.1 to about $50 \mathrm{~s})$.

During the ion-molecule reactions, the neutral reagent (TMB) was present at a constant pressure and its concentration was in excess of that of the ion of interest. Hence, these reactions follow pseudo-first-order kinetics. The reaction efficiencies (Eff. $=\mathrm{k}_{\text {reaction }} / \mathrm{k}_{\text {collision; }}$ the fraction of ion-molecule collisions that results in the formation of products) were determined by using the measured rate of the highly exothermic electron-transfer reaction between argon radical cation and the neutral reagent. Assuming that this exothermic electron-transfer reaction proceeds nearly at the collision rate (with the rate constant $\mathrm{k}_{\text {collision }}$ that can be calculated [18-20]), efficiencies of the ion-molecule reactions can be obtained by using the equation shown below. This equation is based on the ratio of the slopes $\left(\mathrm{k}_{\text {reaction }} \times[\mathrm{TMB}]=\right.$ slope $(\mathrm{IM})$ and $\mathrm{k}_{\text {collision }} \times$ $[\mathrm{TMB}]=$ slope $(\mathrm{ET}))$ of plots of the natural logarithm of the relative abundance of the reactant ion versus time determined for the ion-molecule (IM) and exothermic electron-transfer (ET) reactions (thus eliminating the need to know [TMB]), masses of the ion $\left(\mathrm{M}_{\mathrm{i}}\right)$, neutral reagent $\left(\mathrm{M}_{\mathrm{n}}\right)$, and argon $\left(\mathrm{M}_{(\mathrm{ET})}\right)$, and the pressure measured for
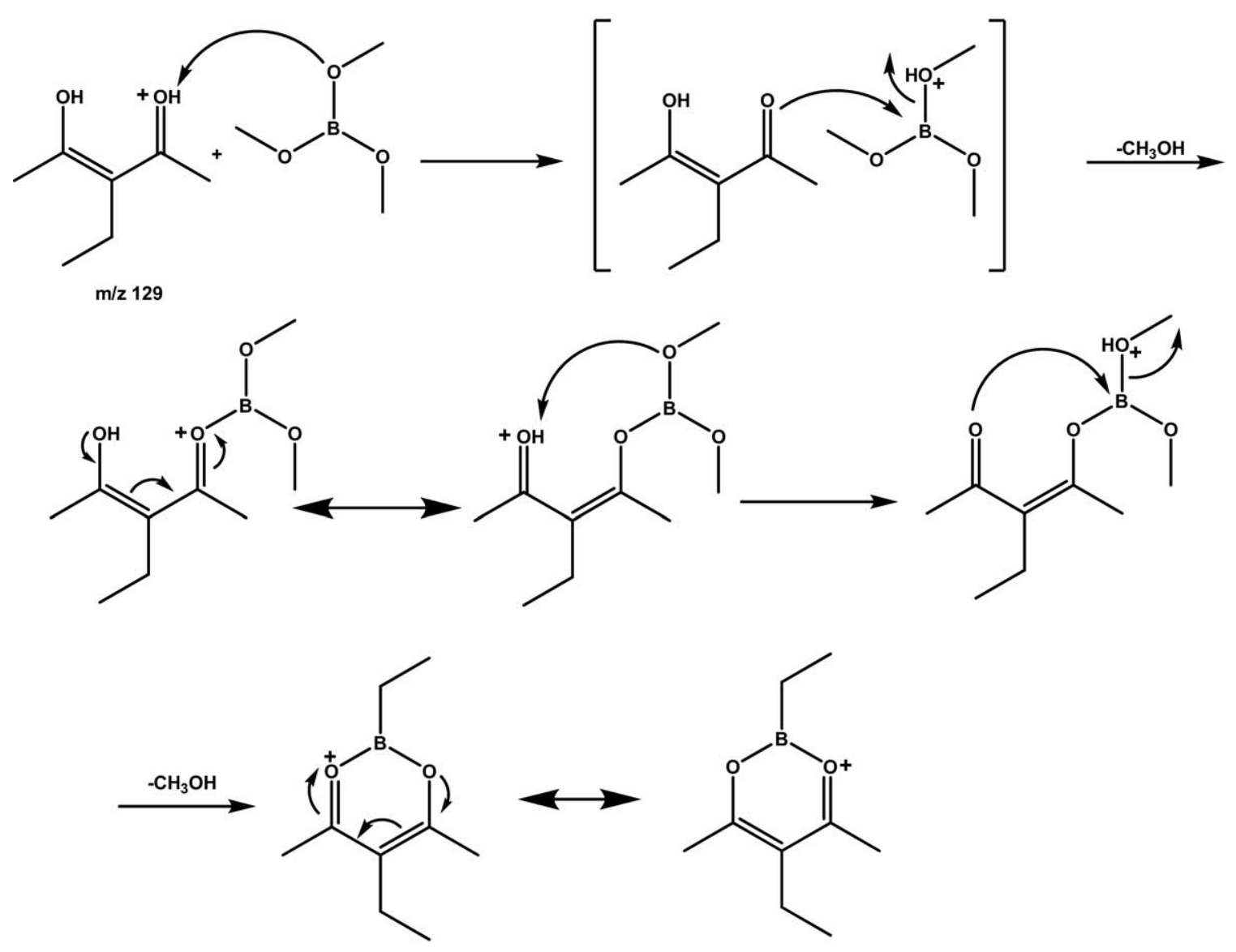

$\mathrm{m} / \mathrm{z} 169$ 
Table 2. Derivatization products $(\mathrm{m} / \mathrm{z}$ values and formation reactions) of reactions between protonated reduced carbonyl compounds and $T M B$, and $H / D$ exchange $\left(\mathrm{D}_{2} \mathrm{O}\right)$ products of the singly derivatized reduced carbonyl compounds

\begin{tabular}{|c|c|c|c|}
\hline Analyte (MW) & $\begin{array}{l}\text { Reduced analyte } \\
\left(\mathrm{m} / \mathrm{z} \text { of }(\mathrm{M}+\mathrm{H})^{+}\right)\end{array}$ & $\begin{array}{c}\text { Singly boron derivatized analyte } \\
\text { (adduct }-\mathrm{CH}_{3} \mathrm{OH} \text { ) and other } \\
\text { products }{ }^{\mathrm{a}}(\mathrm{m} / \mathrm{z})\end{array}$ & $\begin{array}{c}\mathrm{H} / \mathrm{D} \text { exchange of } \\
\text { adduct }-\mathrm{CH}_{3} \mathrm{OH}(\mathrm{m} / \mathrm{z})\end{array}$ \\
\hline ropanalde & Propanol (61) & $\begin{array}{l}\left(1^{\circ}\right) \text { Adduct }-\mathrm{CH}_{3} \mathrm{OH}(133) \\
\left(1^{\circ}\right) \mathrm{TMB}+\mathrm{H}^{+}(105) \\
\left(2^{\circ}\right) 2 \mathrm{TMB}+\mathrm{H}^{+}-\mathrm{CH}_{3} \mathrm{OH}(177)\end{array}$ & $\begin{array}{l}\mathrm{H} / \mathrm{D} \text { exchange product } \\
\text { (134) }\end{array}$ \\
\hline 3-Hydroxy-2-propanone (74) & 1,2-Propanediol (77) & $\begin{array}{l}\left(1^{\circ}\right) \text { Adduct }-\mathrm{CH}_{3} \mathrm{OH}(149) \\
\left(2^{\circ}\right) \text { Adduct }+\mathrm{TMB}-2 \mathrm{CH}_{3} \mathrm{OH}(221) \\
\left(1^{\circ}\right) \mathrm{TMB}+\mathrm{H}^{+}(105) \\
\left(2^{\circ}\right) 2 \mathrm{TMB}+\mathrm{H}^{+}-\mathrm{CH}_{3} \mathrm{OH}(177)\end{array}$ & $\begin{array}{l}\text { Two H/D exchange } \\
\text { products }(150,151)\end{array}$ \\
\hline 5-Hydroxy-2-pentanone (102) & 1,4-Pentanediol (105) & $\begin{array}{l}\left.\left(1^{\circ}\right) \text { Adduct }-\mathrm{CH}_{3} \mathrm{OH}(177)\right) \\
\left(2^{\circ}\right) \text { Adduct }+\mathrm{TMB}-2 \mathrm{CH}_{3} \mathrm{OH}(249)\end{array}$ & $\begin{array}{l}\text { Two H/D exchange } \\
\text { products }(178,179)\end{array}$ \\
\hline 1,4-Cyclohexanedione (112) & 1,4-Cyclohexanediol (117) & $\begin{array}{l}\left(1^{\circ}\right) \text { Adduct }-\mathrm{CH}_{3} \mathrm{OH}(189) \\
\left(2^{\circ}\right) \text { Adduct }+\mathrm{TMB}-2 \mathrm{CH}_{3} \mathrm{OH}(261) \\
\left(2^{\circ}\right) \text { Adduct }+\mathrm{TMB}-3 \mathrm{CH}_{3} \mathrm{OH}(229)\end{array}$ & $\begin{array}{l}\text { Two H/D exchange } \\
\text { products }(190,191)\end{array}$ \\
\hline 3-Ethyl-2,4-pentanedione (128) & 3-Ethyl-2,4-pentanediol (133) & $\begin{array}{l}\left(1^{\circ}\right) \text { Adduct }-\mathrm{CH}_{3} \mathrm{OH}(205) \\
\left(2^{\circ}\right) \text { Adduct }+\mathrm{TMB}-2 \mathrm{CH}_{3} \mathrm{OH}(277) \\
\left(2^{\circ}\right) \text { Adduct }+\mathrm{TMB}-3 \mathrm{CH}_{3} \mathrm{OH}(245)\end{array}$ & $\begin{array}{l}\text { Two H/D exchange } \\
\text { products }(206,207)\end{array}$ \\
\hline $\begin{array}{l}\text { 2,2-Dimethyl-3- hydroxypropanal } \\
\text { (102) }\end{array}$ & $\begin{array}{l}\text { 2,2-Dimethyl-1,3-propanediol } \\
\text { (105) }\end{array}$ & $\begin{array}{l}\left(1^{\circ}\right) \text { Adduct }-\mathrm{CH}_{3} \mathrm{OH}(177) \\
\left(2^{\circ}\right) \text { Adduct }+\mathrm{TMB}-2 \mathrm{CH}_{3} \mathrm{OH}(249)\end{array}$ & $\begin{array}{l}\text { Two H/D exchange } \\
\text { products }(178,179)\end{array}$ \\
\hline
\end{tabular}

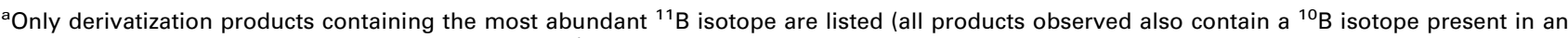
abundance of $25 \%$ relative to the most stable isotope).

$\left(1^{\circ}\right)=$ primary product; $\left(2^{\circ}\right)=$ secondary product.

the neutral reagent during the ion-molecule reaction $\left(\mathrm{P}_{\mathrm{n}(\mathrm{IM})}\right)$ and the electron-transfer reaction $\left(\mathrm{P}_{\mathrm{n}(\mathrm{ET})}\right)$. The accuracy of the efficiencies is estimated to be $\pm 50 \%$, but their precision is better than $\pm 10 \%$.

$$
\begin{aligned}
\text { Efficiency } & =\frac{\text { slope }(\mathrm{IM})}{\text { slope }(\mathrm{ET})} *\left(\frac{\mathrm{M}_{\mathrm{i}}\left(\mathrm{M}_{(\mathrm{ET})}+\mathrm{M}_{\mathrm{n}}\right)}{\mathrm{M}_{(\mathrm{ET})}\left(\mathrm{M}_{\mathrm{i}}+\mathrm{M}_{\mathrm{n}}\right)}\right)^{1 / 2} \\
& *\left(\frac{\mathrm{P}_{\mathrm{n}(\mathrm{ET})}}{\mathrm{P}_{\mathrm{n}(\mathrm{IM})}}\right) * 100
\end{aligned}
$$

After reactions, all ions were excited for detection by using chirp excitation at a bandwidth of $2.7 \mathrm{MHz}$, amplitude of $124 \mathrm{~V}_{p-p}$ and a sweep rate of $3200 \mathrm{~Hz} \mu \mathrm{s}^{-1}$. Background spectra were recorded by removing the ion of interest by SWIFT ejection before reaction or SORI-CAD. All the spectra were background corrected by subtracting the background spectra from the reaction spectra. The spectra were recorded as $128 \mathrm{k}$ data points and by using one zero-fill before Fourier transform.

All theoretical energies were calculated with the Gaussian 98 suite of programs [21]. Geometry opti-

Table 3. Derivatization products $(\mathrm{m} / \mathrm{z}$ values and formation reactions) of reactions between protonated authentic alcohols and diols

\begin{tabular}{|c|c|c|}
\hline $\begin{array}{l}\text { Authentic alcohol } \\
\left(\mathrm{m} / \mathrm{z} \text { of }(\mathrm{M}+\mathrm{H})^{+}\right)\end{array}$ & $\begin{array}{l}\text { Singly boron derivatized analyte (adduct - } \\
\mathrm{CH}_{3} \mathrm{OH} \text { ) and other products }{ }^{\mathrm{a}}(\mathrm{m} / \mathrm{z})\end{array}$ & $\begin{array}{c}\mathrm{H} / \mathrm{D} \text { exchange of } \\
\text { adduct }-\mathrm{CH}_{3} \mathrm{OH}(\mathrm{m} / \mathrm{z})\end{array}$ \\
\hline Propanol (61) & $\begin{array}{l}\left(1^{\circ}\right) \text { Adduct }-\mathrm{CH}_{3} \mathrm{OH}(133) \\
\left(1^{\circ}\right) \mathrm{TMB}+\mathrm{H}^{+}(105) \\
\left(2^{\circ}\right) 2 \mathrm{TMB}+\mathrm{H}^{+}-\mathrm{CH}_{3} \mathrm{OH}(177)\end{array}$ & One H/D exchange product (134) \\
\hline 1,2-Propanediol (77) & $\begin{array}{l}\left(1^{\circ}\right) \text { Adduct }-\mathrm{CH}_{3} \mathrm{OH}(149) \\
\left(2^{\circ}\right) \text { Adduct }+\mathrm{TMB}-2 \mathrm{CH}_{3} \mathrm{OH}(221) \\
\left(1^{\circ}\right) \mathrm{TMB}+\mathrm{H}^{+}(105) \\
\left(2^{\circ}\right) 2 \mathrm{TMB}+\mathrm{H}^{+}-\mathrm{CH}_{3} \mathrm{OH}(177)\end{array}$ & Two H/D exchange products $(150,151)$ \\
\hline 1,4-Pentanediol (105) & $\begin{array}{l}\left(1^{\circ}\right) \text { Adduct }-\mathrm{CH}_{3} \mathrm{OH}(177) \\
\left(2^{\circ}\right) \text { Adduct }+\mathrm{TMB}-2 \mathrm{CH}_{3} \mathrm{OH}(249)\end{array}$ & Two H/D exchange products $(178,179)$ \\
\hline 1,4-Cyclohexanediol (117) & $\begin{array}{l}\left(1^{\circ}\right) \text { Adduct }-\mathrm{CH}_{3} \mathrm{OH}(189) \\
\left(2^{\circ}\right) \text { Adduct }+\mathrm{TMB}-2 \mathrm{CH}_{3} \mathrm{OH}(261) \\
\left(2^{\circ}\right) \text { Adduct }+\mathrm{TMB}-3 \mathrm{CH}_{3} \mathrm{OH}(229)\end{array}$ & Two H/D exchange products $(190,191)$ \\
\hline 2,2-Dimethyl-1,3-propanediol (105) & $\begin{array}{l}\left(1^{\circ}\right) \text { Adduct }-\mathrm{CH}_{3} \mathrm{OH}(177) \\
\left(2^{\circ}\right) \text { Adduct }+\mathrm{TMB}-2 \mathrm{CH}_{3} \mathrm{OH}(249)\end{array}$ & Two H/D exchange products $(178,179)$ \\
\hline
\end{tabular}
with $T M B$, and $\mathrm{H} / \mathrm{D}$ exchange $\left(\mathrm{D}_{2} \mathrm{O}\right)$ products of the singly derivatized alcohols

${ }^{a}$ Only derivatization products containing the most abundant ${ }^{11} \mathrm{~B}$ isotope are listed (all products observed also contain a ${ }^{10} \mathrm{~B}$ isotope present in an abundance of $25 \%$ relative to the most stable isotope).

$\left(1^{\circ}\right)=$ primary product; $\left(2^{\circ}\right)=$ secondary product. 
mizations and vibrational frequency calculations were performed using density functional theory at the B3LYP/6-31G(d) level. All theoretical energies are presented at $0 \mathrm{~K}$ and include zero-point vibrational energy corrections.

Derivatization Procedure for the Reduction of Carbonyl Compounds to the Corresponding Hydroxyl Compounds (Scheme 1)

To one mmol of the carbonyl compound, about $3 \mathrm{ml}$ of methanol was added and stirred for about $5 \mathrm{~min}$. The mixture was placed in an ice bath, and about 1.2 equivalent of $\mathrm{NaBH}_{4}$ was added. Once $\mathrm{H}_{2}$ evolution ceased, the reaction mixture was brought to roomtemperature and stirring continued under $\mathrm{N}_{2}$ atmosphere for about $2 \mathrm{~h}$. The reaction mixture was then exposed to vacuum to remove methanol, followed by addition of water to the resultant solid. The product was extracted by using diethyl ether. Anhydrous $\mathrm{NaHSO}_{3}$ was added to the ether layer followed by filtration. The ether was removed by evaporation and the product was vacuum dried to remove any residual solvent.

\section{Results and Discussion}

Partial Derivatization of the Functional Groups in Protonated Carbonyl Compounds Upon Reaction with $T M B$

The reactions of protonated monofunctional hydroxyl and carbonyl compounds with TMB in the mass spectrometer have been reported to lead to diagnostic
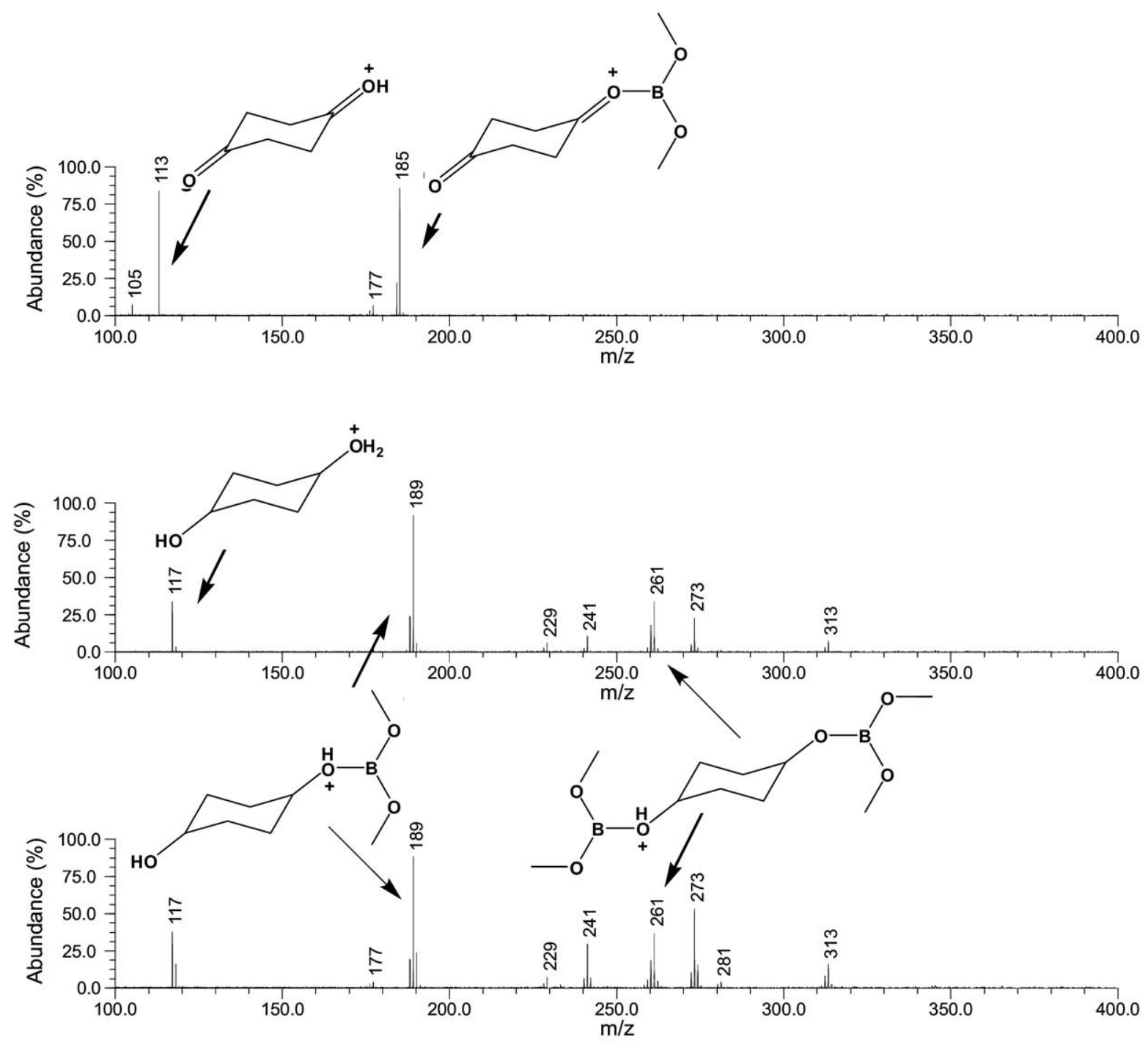

Figure 1. Reaction of TMB with protonated diketone, its reduced form, and an authentic diol. The ions of $\mathrm{m} / \mathrm{z} 241,273,281$, and 313 are chemical impurities formed in reactions of the ions of $\mathrm{m} / \mathrm{z} 117$, 189 , and 229 with TMB diffusing into this cell from the other cell. 
derivatization of the oxygen-containing functional group [11i]. However, derivatization of only the carbonyl functional group was found to take place for hydroxyketones [11i]. These findings were verified by examining the reactions of several protonated model compounds (Table 1). All but one of the protonated bifunctional carbonyl compounds studied react with only one molecule of TMB (instead of the expected two) by addition followed by elimination of a methanol molecule. The reason for this partial derivatization of the bifunctional carbonyl compounds may be the lack of generation of an acidic hydrogen upon derivatization of the first (more basic) functional group, the keto group. In sharp contrast, derivatization of the first functionality in protonated diols generates an acidic hydrogen [11i], which is transferred to another boron reagent molecule and ultimately leads to derivatization of the second functional group. When the singlyderivatized bifunctional carbonyl containing analytes studied here were subjected to SORI-CAD, derivatization of the second functional group took place via elimination of a second methanol molecule (Table 1, Scheme 2).

An exceptional case among the ketones studied is 3-ethyl-2,4-pentanedione. This protonated diketone reacts with TMB by elimination of two methanol molecules, thus undergoing derivatization of both the functional groups, just like protonated diols. Scheme 3 illustrates a possible mechanism for the observed reactivity, based on the expectation that this ketone can exist in the enol form in the collision complex. Another exception is protonated 5-hydroxy-2-pentanone that does not undergo any derivatization with TMB. This lack of derivatization has been attributed [11i] to the substantially higher PA of this ketone (PA 220-222 $\mathrm{kcal} / \mathrm{mol}$; calculated at B3LYP/6-31G(d) level of theory) than that of TMB (195 kcal/mol [22]. The difference in PA between the two is much higher than the solvation energy that can be gained during the formation of the ion-molecule collision complex. Hence, the initial proton transfer step of the derivatization reaction is hindered.
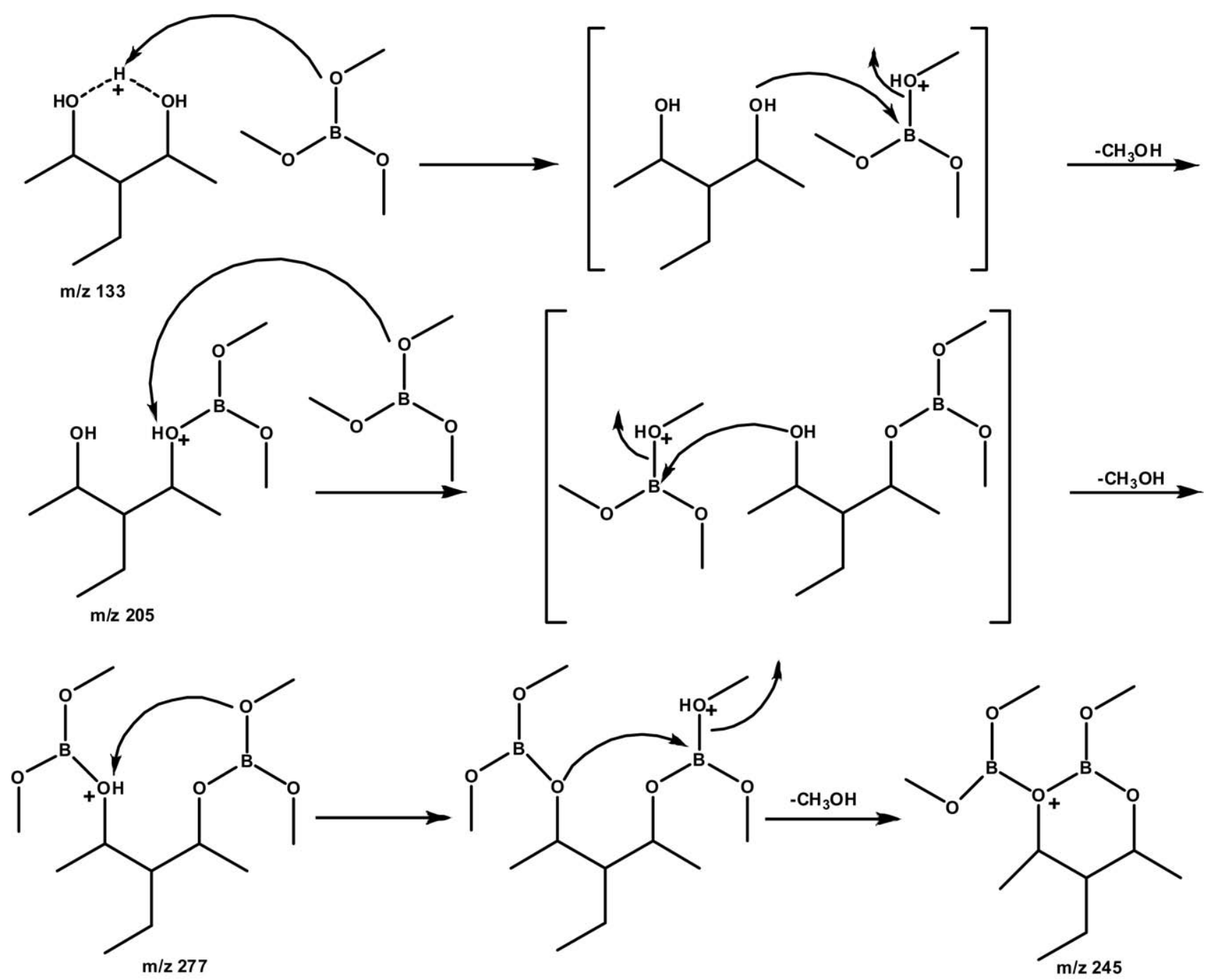

Scheme 4 


\section{Complete Derivatization of Functional Groups Upon Reaction of Solution-Reduced Protonated Carbonyl Compounds with TMB}

The above reactivity studies suggest that the presence of a carbonyl group hinders the derivatization of another oxygen-containing functional group in a protonated analyte via ion-molecule reactions with TMB. On the other hand, our previous studies demonstrate that polyols are among the easiest compounds to analyze by reactions with boron reagents [11i, 23]. The number of hydroxyl groups in polyols can be identified by simply counting the total number of methanol molecules lost upon the reaction of the protonated polyols with $\mathrm{TMB}$, or by counting the total number of TMB molecules added. Hence, conversion of the problematic carbonyl groups to hydroxyl groups before mass spectrometric analysis should facilitate the identification of polyfunctional analytes containing keto groups.

$\mathrm{NaBH}_{4}$ reduction was used to reduce the carbonyl groups of the analytes to hydroxyl groups in solution before mass spectrometric analysis. The reactions of the protonated reduced analytes with TMB were found to lead to derivatization of all the functional groups, as expected (Table 2). The same products were obtained for the commercially available, authentic alcohols and diols (Table 3). Figure 1 shows typical mass spectra obtained upon reaction of TMB with protonated 1,4-cyclohexanone, protonated reduced 1,4-cyclohexanone, and protonated commercially available 1,4-cyclohexanediol. The results obtained for the reduced ketones are similar to those obtained earlier for reactions of protonated diols with TMB and protonated polyols with diethylmethoxyborane [11i, 23]. The derivatization of the first hydroxyl group generates an acidic hydrogen, which is abstracted by a second boron reagent molecule, resulting in the derivatization of the second functionality. This consecutive reaction continues until all the hydroxyl groups are derivatized.

Apart from the above mentioned derivatization products, protonated 3-ethyl-2,4-pentanediol (Scheme 4) and protonated 1,4-cyclohexanediol (Scheme 5) undergo an additional (misleading) intramolecular methanol loss from the doubly-derivatized analyte, forming ions of $\mathrm{m} / \mathrm{z} 245$ and 229 , respectively. The reaction likely involves the migration of the acidic hydrogen from an oxygen atom of the doubly-derivatized analyte to one of the methoxy groups bonded to the boron center. This intramolecular proton transfer is then followed by unimolecular fragmentation (Scheme 5 ) or by nucleophilic addition at the boron atom by a methoxy oxygen attached to the other boron atom, followed by a methanol loss (Scheme 4). Similar observations of intramo-

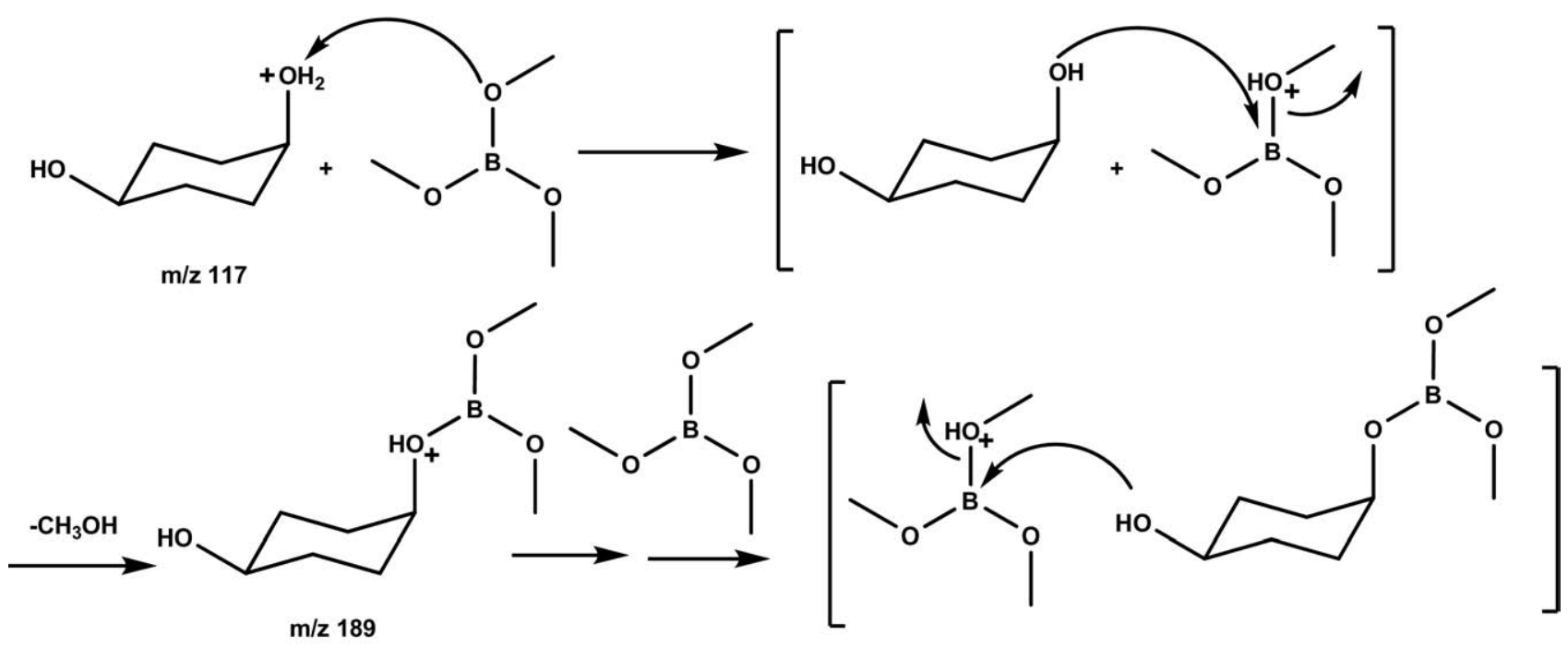<smiles>COB(OC)OC1CCC(OB(OC)OC)CCC(OB(OC)O[B]OC2CCCCC2)CC1</smiles>

Scheme 5 
lecular replacement reactions have been reported in earlier studies [11i, 23, 24].

Thus, using the above approach, the number of carbonyl groups present in a polyfunctional analyte can be determined based on (1) differences in reactivity toward TMB between the protonated reduced and unreduced analyte, and (2) differences in the $\mathrm{m} / \mathrm{z}$ values of the protonated reduced and unreduced analyte.

\section{Reaction Kinetics}

The efficiencies were measured for the reactions of some of the protonated diols with TMB. Protonated 1,2-propanediol was found to react with TMB at an efficiency of $50 \%$, 1,4-pentanediol nearly at $40 \%$, and 3-ethyl-2,4-pentanediol at about $50 \%$. These reaction efficiencies are high, which suggests that these ionmolecule reactions are fast enough for practical applications.
H/D Exchange Reactions of Singly BoronDerivatized Analytes (Adduct- $\mathrm{CH}_{3} \mathrm{OH}$ ) with $\mathrm{D}_{2} \mathrm{O}$ for the Identification of the Functional Groups

Further structural information on the analytes was obtained by examining their $\mathrm{H} / \mathrm{D}$ exchange reactions with deuterium oxide. This experiment also allows sorting out the misleading elimination of three methanol molecules upon reactions of TMB with protonated 3-ethyl-2,4-pentanediol and 1,4-cyclohexanediol that only contain two hydroxyl groups. When allowed to react with deuterium oxide, the singly TMB-derivatized alcohols and diols undergo either one or two H/D exchanges depending on the number of hydroxyl groups present (Tables 2 and 3, Figure 2). Accordingly, singly-derivatized 3-ethyl-2,4-pentanediol and 1,4cyclohexanediol undergo two H/D exchanges, which reveals the presence of two hydroxyl groups. In contrast, singly-derivatized carbonyl compounds do not

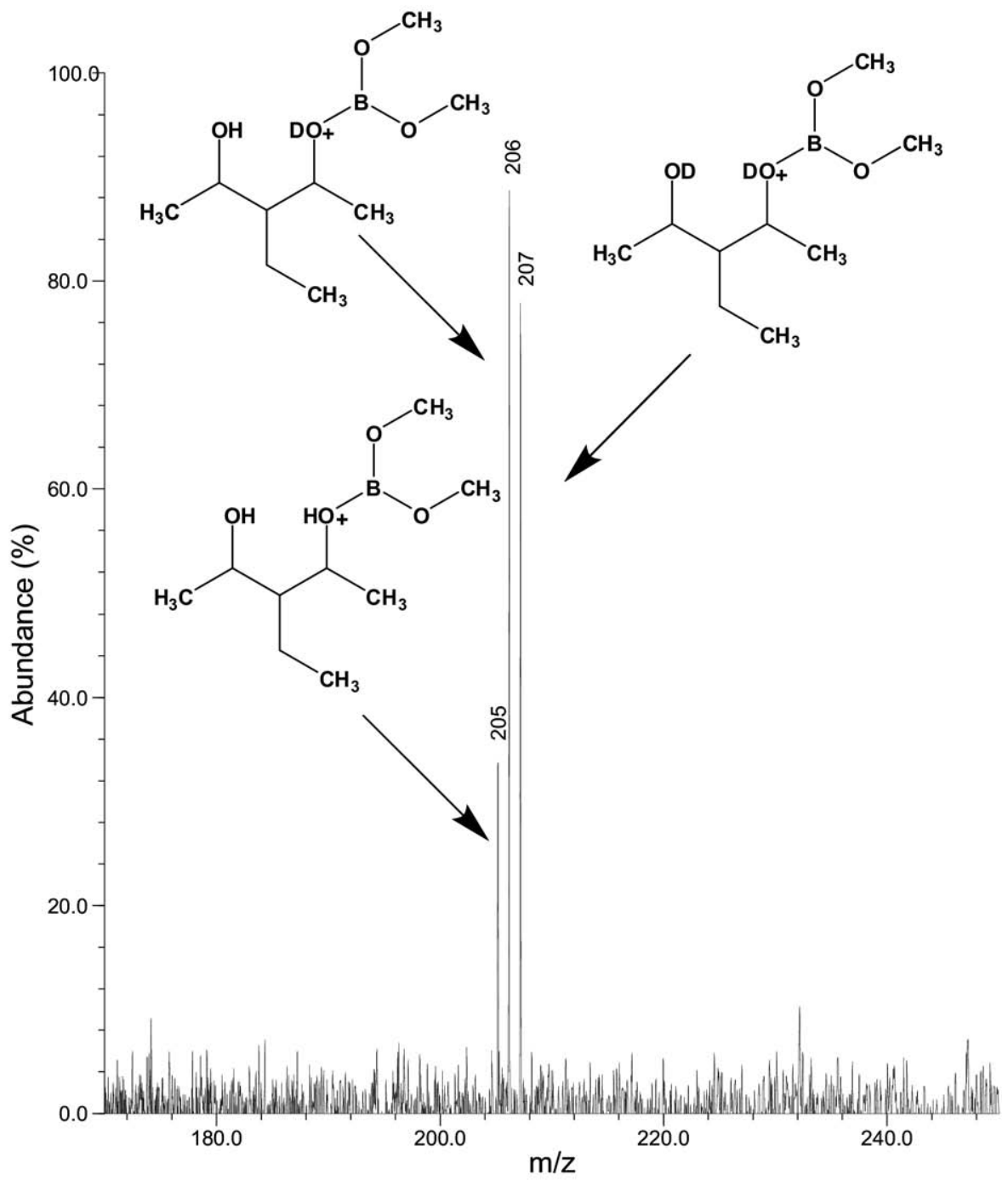

Figure 2. H/D exchange mass spectrum of the singly-derivatized 3-ethyl-2,4-pentanediol (adduct$\mathrm{CH}_{3} \mathrm{OH}$ ). 

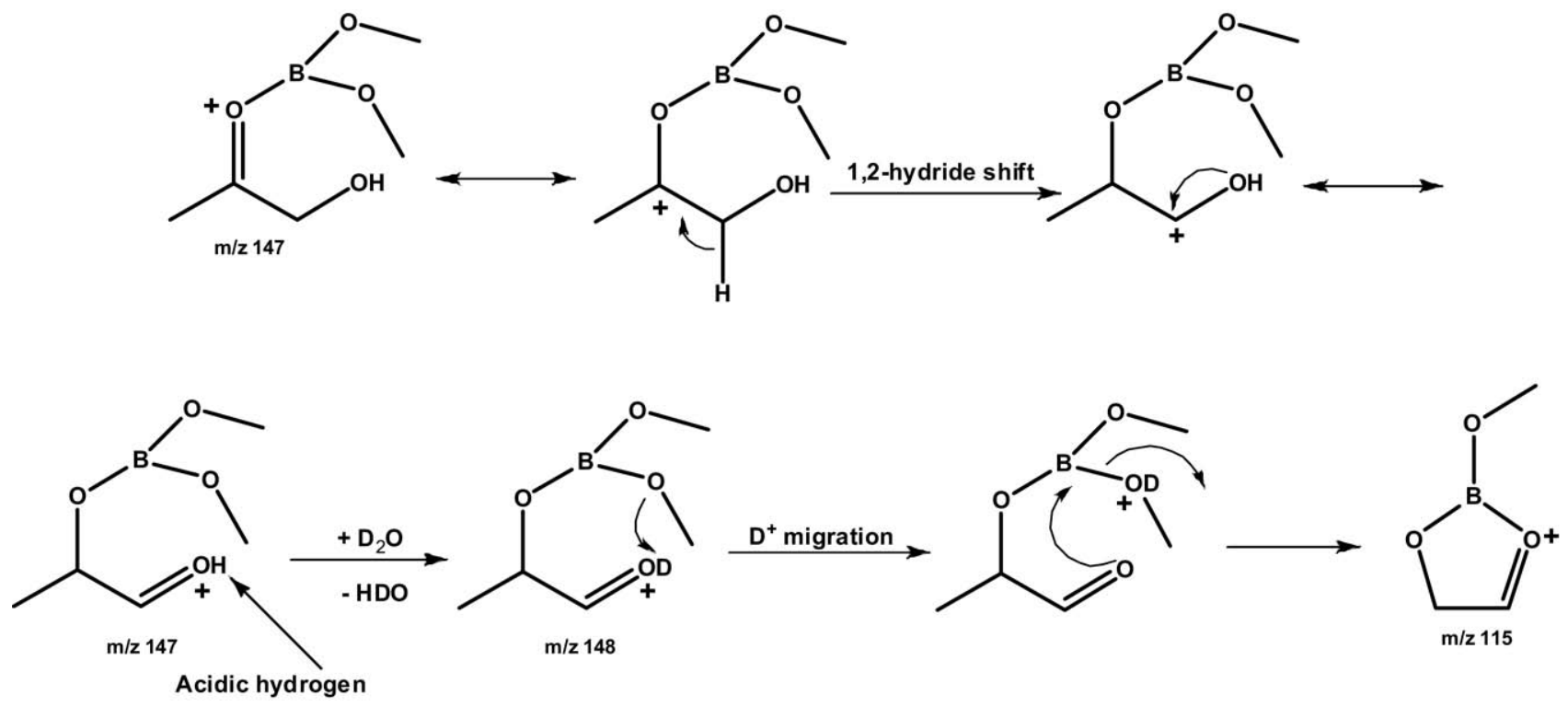

Scheme 6

undergo $\mathrm{H} / \mathrm{D}$ exchange reactions, with the exception of 3-hydroxy-2-propanone (Table 1). The singly-derivatized 3-hydroxy-2-propanone undergoes one H/D exchange. This unique reactivity may be attributed to a favorable 1,2-hydride shift, which leads to the formation of an acidic hydrogen (Scheme 6).

Thus, the hydroxyl groups in the above analytes can be counted by performing H/D exchange reactions. The number of $\mathrm{H} / \mathrm{D}$ exchange products is equivalent to the number of hydroxyl groups present in the analyte. Further H/D exchange studies allow the differentiation of carbonyl functionalities from hydroxyl functional groups.

\section{Conclusions}

Protonated monofunctional carbonyl compounds and alcohols react with TMB in an FT-ICR mass spectrometer by proton transfer to TMB followed by addition of the neutral analyte to the protonated TMB and elimination of a methanol molecule. However, the reactions of protonated hydroxyketones with TMB were found to lead to only partial derivatization of the functional groups, with a few exceptions. Since the number of hydroxyl groups in polyols are readily determined by simply counting the total number of methanol molecules lost upon the reaction of protonated polyols with $\mathrm{TMB}$ or by counting the total number of TMB molecules added, solution reactions were used to convert the carbonyl groups to hydroxyl groups before mass spectrometric analysis. Gas-phase ion-molecule reactions of the resulting protonated hydroxyl compounds with TMB lead to complete derivatization of all the functional groups. Thus, using this approach, the number of carbonyl groups present in the unreduced analyte can be determined based on (1) differences in reactivity between the protonated reduced and unreduced ana- lyte toward TMB in the gas phase, and (2) differences in the $\mathrm{m} / \mathrm{z}$ values of the protonated reduced and unreduced analyte. The number of hydroxyl functionalities in an analyte can be unambiguously determined by examining H/D exchange reactions of the singly-derivatized analyte.

In summary, the current approach has been shown to be successful in the identification and counting of carbonyl and hydroxyl groups in some simple organic compounds (with one exception, the 5-hydroxy-2-pentanone, which has an exceptionally high PA for an oxygencontaining analyte). Hence, this method should be applicable to most small analytes containing oxygen functionalities, including sugars and many steroids. Future work will involve adopting this approach for the identification and counting of functional groups in multifunctional compounds.

\section{Acknowledgments}

The authors gratefully acknowledge Eli Lilly and Co. and the National Science Foundation for providing financial support for this work.

\section{References}

1. Peiris, D. M.; Lam, W.; Michael, S.; Ramanathan, R. Distinguishing N-Oxide and Hydroxyl Compounds: Impact of Heated Capillary/ Heated Ion Transfer Tube in Inducing Atmospheric Pressure Ionization Source Decompositions. J. Mass Spectrom. 2004, 39, 600-606.

2. de Hoffmann, E. Tandem Mass Spectrometry: A Primer. J. Mass Spectrom. 1996, 31, 129-137.

3. (a) Halket, J. M.; Waterman, D.; Przyborowska, A. M.; Patel, R. K. P. Fraser, P.D.; Bramley, P. M. Chemical Derivatization and Mass Spectral Libraries in Metabolic Profiling by GC/MS and LC/MS/MS. J. Exp. Bot. 2005, 56, 219-243. (b) Petrović, M.; Hernando, M. D.; Silvia Díaz-Cruz, M.; Barceló, D. Liquid Chromatography-Tandem Mass Spectrometry for the Analysis of Pharmaceutical Residues in Environmental Samples: A Review. J. Chromatogr. A 2005, 1067, 1-14. (c) Levsen, K.; Schiebel, H.-M.; Behnke, B.; Dötzer, R.; Dreher, W.; Elend, M.; Thiele, H. Structure Elucidation of Phase II Metabolites by Tandem Mass Spectrometry: An Overview. J. Chromatogr. A 2005, 1067, 55-72. (d) Xu, X.; Lan, J.; 
Korfmacher, W. A. Rapid LC/MS/MS Method Development for Drug Discovery. Anal. Chem. 2005, 77, 389A-394A.

4. (a) Bossio, R. E.; Marshall, A. G. Baseline Resolution of Isobaric Phosphorylated and Sulfated Peptides and Nucleotides by Electrospray Ionization FTICR MS: Another Step Toward Mass Spectrometry-Based Proteomics. Anal. Chem. 2002, 74, 1674-1679. (b) Guan, S.; Marshall, A. G. Scheppele, S. E. Resolution and Chemical Formula Identification of Aromatic Hydrocarbons and Aromatic Compounds Containing Sulfur, Nitrogen, or Oxygen in Petroleum Distillates and Refinery Streams. Anal. Chem. 1996, 68, 46-71.

5. (a) Busch, K. L.; Glish, G. L.; McLuckey, S. A. Mass Spectrometry/Mass Spectrometry: Techniques and Applications of Tandem Mass Spectrometry; VCH Publishers: New York, 1988. (b) Yost, R. A.; Fetterolf, D. D Tandem Mass Spectrometry (MS/MS) Instrumentation. Mass Spectrom. Rev. 1983, 2, 1-45

6. (a) Engen, J. R.; Smith, D. L. Investigating Protein Structure and Dynamics by Hydrogen Exchange MS. Anal Chem. 2001, 73(9), 256A265A. (b) Bienvenut, W. V.; Hoogland. C.; Greco, A.; Heller, M.; Gasteiger, E.; Appel, R. D.; Diaz, J-J.; Sanchez, J-C.; Hochstrasser, D. F. Hydrogen/Deuterium Exchange for Higher Specificity of Protein Identification by Peptide Mass Fingerprinting. Rapid. Commun. Mass Spectrom. 2002, 16(6), 616-626. (c) Yan, X.; Watson, J.; Ho, P. S.; Deinzer, M. L. Mass Spectrometric Approaches Using Electrospray Ionization Charge States and Hydrogen-Deuterium Exchange for Determining Protein Structures and Their Conformational Changes. Mol. Cell. Proteom., 2004, 3, 10-23.

7. (a) Brodbelt, J. S. Analytical Applications of Ion-molecule Reactions. Mass Spectrom. Rev. 1997, 16, 91-110. (b) Eberlin, M. N. Structurally Diagnostic Ion-Molecule Reactions: Class and Functional-group Identification by Mass Spectrometry. J. Mass Spectrom. 2006, 41, 141-156. (c) Sawyer, H. A.; Marini, J. T.; Stone, E. G.; Ruotolo, B. T.; Gillig, K. J.; Russell, D. H. The Structure of Gas-Phase Bradykinin Fragment 1-5 (RPPGF) Ions: An Ion Mobility Spectrometry and H/D Exchange Ion-Molecule Reaction Chemistry Study. J. Am. Soc. Mass Spectrom. 2005, 16, 893-905. (d) Gronert, S.; Huag, R.; Li. K. H. Gas Phase Derivatization in Peptide Analysis. I: The Utility of Trimethyl Borate in Identifying Phosphorylation Sites. Intl. J. Mass Spectrom. 2004, 231, 179-187. (e) Freitas, M. A.; O'Hair, R. A. J.; Dua, S.; Bowie, J. H. The Methoxymethyl Cation Cleaves Peptide Bonds in The Gas Phase. Chem. Commun. 1997, 15, 1409-1410. (f) Gronert, S. Mass Spectrometric Studies of Organic Ion/Molecule Reactions. Chem. Rev. 2001, 101, 329-360. (g) Gronert, S. Quadrupole Ion Trap Studies of Fundamental Organic Reactions. Mass Spectrom. Rev. 2005, 24, 100-120. (h) Reid, G. E.; Tichy, S. E.; Perez, J.; O'Hair, R. A. J.; Simpson, R. J.; Kenttämaa, H. I. N-Terminal Derivatization and Fragmentation of Neutral Peptides Via Ion-Molecule Reactions with Acylium Ions: Toward Gas-Phase Edman Degradation? J. Am. Chem. Soc. 2001, 123, 1184-1192. (i) O'Hair, R. A. J.; Androutsopoulos, N. K.; Reid, G. E. Do Amines React With Protonated Peptides in The Gas Phase Via Transacylation Reactions to Induce Peptide Bond Cleavage? Rapid Commun. Mass Spectrom. 2000, 14, 17071716. (j) Reid, G. E.; Simpson, R. J.; O'Hair, R. A. J. Probing the Fragmentation Reactions of Protonated Glycine Oligomers via Multistage Mass Spectrometry and Gas Phase Ion Molecule Hydrogen/ Deuterium Exchange. Intl. J. Mass Spectrom. 1999, 190/191, 209-230. (k) O'Hair, R.; Reid, G. E. Derivatization of Protonated Peptides via Gas Phase Ion-Molecule Reactions with Acetone. J. Am. Soc. Mass Spectrom. 2000, 11, 244-256. (1) Orlando, R.; Fenselau, C.; Cotter, R. J. Endothermic Ion-Molecule Reactions. J. Am. Soc. Mass Spectrom. 1991, 2, 189-197. (m) Orlando, R.; Fenselau, C.; Cotter, R. J. Site-Directed Fragmentation in $\mathrm{N}$-acetylated Oligosaccharides at Low Beam Energies. Anal. Chem. 1990, 62, 2388-2390. (n) Orlando, R. Fenselau, C. Cotter, R. J. Remote-Site Fragmentation at Very Low Kinetic Energies. Org. Mass Spectrom. 1990, 25, 485-489. (o) Hunt, D. F.; Sethi, S. K. Gas-phase Ion/Molecule Isotope-Exchange Reactions: Methodology for Counting Hydrogen Atoms in Specific Organic Structural Environments by Chemical Ionization Mass Spectrometry. J. Am. Chem. Soc. 1980, 102(23), 6953-6963.

8. (a) Staley, R. H.; Corderman, R. R.; Foster, M. S.; Beauchamp, J. L. Nucleophilic Attack Protonated Oxiranes in the Gas Phase. Identification of the $\mathrm{C} 2 \mathrm{H} 5 \mathrm{O}+$ Isomeric Ion Corresponding to Protonated Ethylene Oxide. I. Am. Chem. Soc. 1974, 96, 1260-1261. (b) Kass, S. R.; Filley, J.; Van. Doren, J. M.; DePuy, C. H. Nitrous Oxide in Gas-Phase Ion-Molecule Chemistry: A Versatile Reagent for the Determination of Carbanion Structure. J. Am. Chem. Soc. 1986, 108, 2849-2852. (c) Tolf, B. R.; Jiang, X. Y.; Wegmann-Szente, A.; Kehres, L. A.; Bunnenberg, E. Djerassi, C. Enhanced. Structural Determination of Substituted Porphyrins by Ammonia Desorption Chemical Ionization Mass Spectrometry. J. Am. Chem. Soc. 1986, 108, 1363-1374. (d) Whitehill, A. B.; George, M.; Gross, M. L. Reactions of Polycyclic Aromatic Hydrocarbon Radical Cations with Model Biological Nucleophiles. J. Am. Soc. Mass. Spectrom. 1996, 7, 628-638. (e) Gross, M. L.; Lin, P.-H.; Franklin, S. J. Identification of $\mathrm{C} 5 \mathrm{H} 10$ Isomers by Ion Cyclotron Resonance Spectrometry. Anal. Chem. 1972, 44, 974-978. (f) Xia, Y.; Chrisman, P. A.; Pitteri, S. J.; Erickson, D. E.; McLuckey, S. A. Ion/Molecule Reactions of Cation Radicals Formed from Protonated Polypeptides Via Gas-Phase Ion/Ion Electron Transfer. J. Am. Chem. Soc. 2006, 128, 11792-11798. (g) O'Hair, R. A. J.; McLuckey, S. A. Trimethylsilyl Derivatization of Nucleic Acid Anions in the Gas Phase. Int. J. Mass Spectrom. Ion Processes 1997, 162, 183-202. (h) Orlando, R.; Murphy, C.; Fenselau, C.; Hansen, G.; Cotter R. J. Strategies for Tandem Mass Spectrometric Structural Analyses of Large Biomolecules. Anal. Chem. 1990, 62, 125-129. (i) Hunt, D. F.;
Shabanowitz, J.; Harvey, T. M.; Coates, M. L. Analysis of Organics in the Environment by Functional Group Using a Triple Quadrupole Mass Spectrometer. J. Chromatogr. 1983, 271, 93-105.

9. (a) Ranatunga, T. D.; Kenttämaa, H. I. Gas-Phase Reactions of Dicoordinated Boron Cations with Alcohols. Inorg. Chem. 1995, 34, 18-27. (b) Ranatunga, T. D.; Kennedy, J. M.; Kenttämaa, H. I. Disubstituted Boron Cations Cleave Carbonyl Bonds. J. Am. Chem. Soc. 1997, 119, 5200-5207. (c) Ranatunga, T. D.; Kenttämaa, H. I. Dicoordinated Boron Cations Dehydrate Organic Ethers in the Gas Phase. J. Am. Chem. Soc. 1992, 114 8600-8604. (d) Kempen, E. C.; Brodbelt, J. Use of Trimethyl Borate as a Chemical Ionization Reagent for the Analysis of Biologically Active Molecules. J. Mass Spectrom. 1997, 32, 846-854. (e) Suming, H.; Yaozu, C.; Longfei, J.; Shuman, X. Chemical-Ionization Mass Spectra of Some Cyclic Glycols and Mono- and Disaccharides Using Trimethyl Borate as Reagent Gas. Org. Mass Spectrom. 1985, 20, 719-723.

10. (a) Thoen, K. K.; Gao, L.; Ranatunga, T. D.; Vainiotalo, P.; Kenttämaa, H. I. Stereoselective Chemical Ionization Mass Spectrometry: Reactions of CH3OPOCH3 + with Cyclic Vicinal Diols. J. Org. Chem. 1997, 62, 8702-8707. (b) Petucci, C.; Guler, L.; Kenttämaa, H. I. Differentiation of Stereoisomeric Steroids by Reactions with Phosphenium Ions. J. Am Soc. Mass Spectrom. 2002, 13, 362-370. (c) Thompson, R. S.; Guler, L. P.; Nelson, E. D.; Yu, Y.-Q.; Kenttämaa, H. I. Mechanistic Study of Stereoselective Gas-Phase Reactions of Phosphenium Ions with cis- and trans-1,2-Diaminocyclohexanes. J. Org. Chem. 2002, 67, 5076-5084.

11. (a) Kenttämaa, H. I.; Cooks, R. G. Identification of Protonated $\beta$ Hydroxycarbonyl Compounds by Reactive Collisions in Tandem Mass Spectrometry. J. Am. Chem. Soc. 1989, 111, 4122-4123. (b) Kenttämaa, H. I.; Pachuta, R. R.; Rothwell, A. P.; Cooks, R. G. Experimental Study of the Potential Energy Surface of the Protonated Cyclohexene Oxide/ Cyclohexanone System. Isomerization, Dissociation, and Ion-Molecule Reaction of the Isolated Ions in the Gas Phase. J. Am. Chem. Soc. 1989 111, 1654-1665. (c) Watkins, M. A.; Price, J. M.; Winger, B. E.; Kenttämaa, H. I. Ion-Molecule Reactions for Mass Spectrometric Identification of Functional Groups in Protonated Oxygen-Containing Monofunctional Compounds. Anal. Chem. 2004, 76, 964-976. (d) Stephenson, J. L. McLuckey, S. A. Counting Basic Sites in Oligopeptides Via Gas-phase Ion Chemistry. Anal. Chem. 1997, 69, 281-285. (e) McLuckey, S. A.; Wells, J. M.; Stephenson, J. L.; Goeringer, D. E. Novel Quadrupole Ion Trap Methods for Characterizing the Chemistry of Gaseous Macro-Ions. Intl. J. Mass Spectrom. 2000, 200, 137-161. (f) Leavell, M. D.; Kruppa, G. H.; Leary, J. A. Determination of Phosphate Position in Hexose Monosaccharides Using an FTICR Mass Spectrometer: Ion/Molecule Reactions, Labeling Studies, and Dissociation Mechanisms. Intl. J. Mass Spectrom. 2003, 222, 135-153. (g) Leavell, M. D.; Leary, J. A. Probing Isomeric Differences of Phosphorylated Carbohydrates Through the Use of Ion/Molecule Reactions and FT-ICR MS. I. Am. Soc. Mass Spectrom. 2003, 14, 323-331. (h) Leavell, M. D.; Kruppa, G. H.; Leary, J. A. Analysis of Phosphate Position in Hexose Monosaccharides Using Ion-Molecule Reactions and SORI-CID on an FT-ICR Mass Spectrometer. Anal. Chem. 2002, 74, 2608-2611. (i) Somuramasami, J.; Duan, P.; Watkins. M. A.; Winger, B. E.; Kenttämaa, H. I. Ion-Molecule Reactions of Trimethylborate Allow the Mass Spectrometric Identification and Counting of Functional Groups in Protonated Bifunctional Oxygen-Containing Compounds and Polyols. Intl. J. Mass Spectrom. 2007, 265, 359-371.

12. (a) Brooks, C. J. W.; Watson, J. Characterization of 1,2- and 1,3-Diols by Gas Chromatography-mass Spectrometry of Cyclic Boronate Esters. Chem. Com. 1967, 952-953. (b) Anthony, G. M.; Brooks, C. J. W.; Maclean, I.; Sangster, I. Cyclic. Boronates as Derivatives for Gas Chromatography. J. Chromatogr. Sci. 1969, 7, 623-631. (c) Harvey, D. J. Cyclic. Alkylboronates as Derivatives for the Characterization of Cannabinolic Acids by Combined Gas Chromatography and Mass Spectrometry. Biomed. Mass Spectrom. 1977, 4, 88-93. (d) Brooks, C. J. W.; Middleditch, B. S.; Anthony, G. M. Mass Spectra of Some 1,3,2-oxazaborolidines. Org. Mass Spectrom. 1969, 2, 1023-1032. (e) Cagnasso, M.; Biondi, P. A. Methane- and. N-Butaneboronates: New Derivatives for Gas Chromatographic Analysis of 3-methoxy-4-hydroxyphenylethylenglycol. Anal. Biochem. 1976, 71, 597-600. (h) Gaskell, S. J.; Edmonds, C. G.; Brooks, C. J. W. Cyclic Boronate Derivatives in Combined Gas Chromatography-Chemical Ionization Mass Spectrometry. Anal. Lett. 1976, 9, 325340. (i) Taylor, P. L. The 8-isoprostaglandins: Evidence for Eight Compounds in Human Semen. Prostaglandins 1979, 17, 259-267. (j) Gaskell, S. J.; Brooks, C. J. W. Electron Impact and Chemical Ionization Mass Spectrometry of Cyclic Boronate Derivatives of Sphingosines and Related Compounds. Org. Mass Spectrom. 1977, 12, 651-658.

13. (a) Wiecko, J.; Sherman, W. R. Boroacetylation of Carbohydrates. Correlations Between Structure and Mass Spectral Behavior in Monoacetylhexose Cyclic Boronic Esters. J. Am. Chem. Soc. 1976, 98, 76317637. (b) Tsuchida, H.; Kitamura, K.; Komoto, M.; Akimori, N. GasLiquid Chromatography and Mass Spectrometry of Trimethylsilyl Ethers and Butaneboronate-Trimethylsilyl Derivatives of Polyhydroxyalkylpyrazines. Carbohydr. Res. 1978, 67, 549-563. (c) Wiecko, J.; Sherman, W. R. Structures and Mass Spectral Behavior of the Inositol Cyclic Boronic Esters. J. Am. Chem. Soc. 1979, 101, 979-983. (d) Anthony, G. M. Brooks, C. J. W.; Middleditch, B. S. Use of Boronate Derivatives in the Characterization of Catecholamines and Related $\beta$-Hydroxy-Amines by Gas Liquid Chromatography-Mass Spectrometry. J. Pharm. Pharacol. 1970, 22, 205-213. (e) Gaskell, S. J.; Edmonds, C. G.; Brooks, C. J. W Applications of Boronate Derivatives in the Study of Ceramides by Gas-Liquid Chromatography-Mass Spectrometry. J. Chromatogr. 1976, 126, 591-599. (f) Brooks, C. J. W.; Harvey, D. J. Comparative Gas 
Chromatographic Studies of Corticosteroid Boronates. J. Chromatogr. 1971, 54, 193-204. (g) Brooks, C. J. W.; Middleditch, B. S.; Harvey, D. J. Mass Spectra of Some Corticosteroid Boronates. Org. Mass Spectrom. 1971, 5 , 1429-1453. (h) Baillie, T. A.; Brooks, C. J. W.; Middleditch, B. S. Comparison of Corticosteroid Derivatives by Gas Chromatography-Mass Spectrometry. Anal. Chem. 1972, 44, 30-37. (i) Gaskell, S. J.; Brooks, C. J. W. New Derivatives for the Analysis of Sphingosine Long-chain Bases by Gas-Liquid Chromatography-Mass Spectrometry. J. Chromatogr. 1976, 122, 415-423

14. Campbell, K. M.; Watkins, M. A.; Li, S.; Fiddler, M. N.; Winger, B. E.; Kenttämaa, H. I. Functional Group Selective Ion/Molecule Reactions: Mass Spectrometric Identification of the Amido Functionality in Protonated Monofunctional Compounds. J Org. Chem. 2007, 72, 3159-3165.

15. Dunbar, R. C. Infrared Radiative Cooling of Gas-Phase Ions. Mass Spectrom. Rev. 1992, 11, 309-339.

16. (a) Chen, L.; Wang, T. C. L.; Ricca, T. L.; Marshall, A. G. Phasemodulated Stored Waveform Inverse Fourier Transform Excitation for Trapped Ion Mass Spectrometry. Anal. Chem. 1987, 59, 449-454. (b) Marshall, A. G.; Wang, T. C. L.; Ricca, T. L. Tailored Excitation for Fourier Transform Ion Cyclotron Mass Spectrometry. J. Am. Chem. Soc. 1985, 107, 7893-7897.

17. Gauthier, J. W.; Trautman, T. R.; Jacbson, D. B. Sustained Off-Resonance Irradiation for Collision-activated Dissociation Involving Fourier Transform Mass Spectrometry. Collision-activated Dissociation Technique That Emulates Infrared Multiphoton Dissociation. Anal. Chim. Acta 1991, 246, 211-225.

18. Bartmess, J. E.; Georgiadis, R. M. Empirical Methods for Determination of Ionization Gage Relative Sensitivities for Different Gases. Vacuum 1983, 33, 149-153

19. (a) Leeck, D. T.; Stirk, K. M.; Zeller, L. C.; Kiminkinen, L. K. M.; Castro, L. M.; Vainiotalo, P.; Kenttämaa, H. I. The Long-Lived Radical Cations of Simple Carbon Esters Isomerize to the Lowest-Energy Structure. J. Am. Chem. Soc. 1994, 116, 3028-3038. (b) Thölmann, D.; Grützmacher, H.-F. Reactions of Dihalobenzene Radical Cations with Ammonia in the Gas Phase. Reactivity Pattern for Nucleophilic Aromatic Substitution. J. Am. Chem. Soc. 1991, 113, 3281-3287.

20. Su, T.; Chesnavich, W. J. Parametrization of the Ion-Polar Molecule Collision Rate Constant by Trajectory Calculations. J. Chem. Phys. 1982, $76,5183-5185$.

21. Frisch, M. J.; Trucks, G. W.; Schlegel, H. B.; Scuseria, G. E.; Robb, M. A.; Cheeseman, J. R.; Zakrzewski, V. G.; Montgomery, J. A. Jr.; Stratmann, R. E.; Burant, J. C.; Dapprich, S.; Millam, J. M.; Daniels, A. D.; Kudin K. N.; Strain, M. C.; Farkas, O.; Tomasi, J.; Barone, V.; Cossi, M.; Cammi, R.; Menucci, B.; Pomelli, C.; Adamo, C.; Clifford, S.; Ochterski, J. Petersson, G. A.; Ayala, P. Y.; Cui, Q.; Morokuma, K.; Malick, D. K.; Rabuck, A. D.; Raghavahari, K.; Foresman, J. B.; Cioslowski, J.; Ortiz, J. V.; Baboul, A. G.; Stefanov, B. B.; Liu, G.; Liashenko, A.; Piskorz, P.; Komaromi, I.; Gomperts, R.; Martin, R. L.; Fox, D. J.; Keith, T.; Al-Laham, M. A.; Peng, C. Y.; Nanayallara, A.; Gonzalez, C.; Challacombe, M.; Gill, P. M. W.; Johnson, B.; Chen, W.; Wong, M. W.; Andres, J. L.; Gonzalez, C.; Head-Gordon, M.; Replogle, E. S.; Pople, J. A. Gaussian 98; Gaussian, Inc.: Pittsburg, PA, 1998.

22. Hunter, E. P. Lias, S. G. Evaluated Gas Phase Basicities and Proton Affinities of Molecules: An Update. J. Phys. Chem. Ref. Data 1998, 27, 413-656.

23. Watkins, M. A.; Winger, B. E.; Shea, R. C.; Kenttämaa, H. I. Ion-Molecule Reactions for the Characterization of Polyols and Polyol Mixtures by ESI/FT-ICR Mass Spectrometry. Anal. Chem. 2005, 77, 1385-1392.

24. Kiplinger, J. P.; Crowder, C. A.; Sorensen, D. N.; Bartmess, J. E. Gas-Phase Ion-molecule Chemistry of Borate and Boronate Esters. J. Am. Soc. Mass Spectrom. 1994, 5, 169-176. 